\title{
A MEGBOCSÁTÁS PSZICHOLÓGIÁJA: KIALAKULÁSA, HATÁSAI ÉS FEJLESZTÉSE
}

\author{
SZONDY MÁTÉ* \\ ELTE PPK Pszichológiai Intézet, Személyiség- \\ és Egészségpszichológiai Tanszék \\ 1064 Budapest, Izabella u. 46.
}

(Beérkezett: 2005. december 26.; elfogadva: 2006. január 4.)

\begin{abstract}
A megbocsátás az interperszonális sérelmekre adott egyik lehetséges válasznak tekinthetô, melynek fókuszában a sérelmet elszenvedő személy kognitív, érzelmi és viselkedéses válaszaiban bekövetkezố proszociális változás áll. A megbocsátás mentális és fizikai egészségre kifejtett pozitív hatása jól dokumentált. Magas szintje alacsony szorongás- és depressziószinttel társul, illetve sikeresen csökkenti a stresszre adott fizikai választ (kortizol és kardiovaszkuláris reaktivitás). A megbocsátást - hatásai alapján - olyan emóció fókuszú megküzdési módként definiálhatjuk, mely sikeresen csökkenti az interperszonális sérelem nyomán kialakult stresszreakciót. Az utóbbi években számos intervenciós technikát dolgoztak ki, melyek a megbocsátás támogatását, illetve fejlesztését tưzték ki célként. Ezek a módszerek általában sikeresen növelik a megbocsátásra való hajlandóságot.
\end{abstract}

Kulcsszavak: megbocsátás, megbocsátás hatásai, megbocsátást elősegítő intervenciók

A történelemkönyveket, illetve a napilapokat lapozva úgy túnik, hogy a humán lények veleszületett tulajdonsága, hogy az interperszonális sérelmeket megtorolják. Ez a hajlamunk nem genetikai elózmények nélkül való: primátáknál (például csimpánzoknál) jól megfigyelhetóek a sérelemre, támadásra adott megtorló válaszok (Aureli és mtsai 1992; de Waal 1996). Pszichológiailag motiváltak vagyunk a rajtunk esett sérelmek megtorlására. Reiss és Havercamp (1998) motivációs rendszerében a bosszú is helyet kap a 15 alapvetô emberi motívum közt.

\footnotetext{
* E-mail: szondymate@freemail.hu
} 
Az eredeti sérelmet és az érte adott megtorlást azonban a legritkább esetben észlelik azonos súlyúnak a résztvevő felek (McCullough és Witvliet 2002). Az áldozatok az okozott kárt sokkal súlyosabbnak és fájdalmasabbnak ítélik, mint az elkövetók. ${ }^{1}$ Ezenkívül, ha az áldozat megbosszulja a sérelmet, akkor az eredeti elkövetô súlyosabbnak látja a bosszút, mint saját tettét - így beindul a bosszúállás „ördögi köre” (Baumeister és mtsai 1998).

Ennek - az interperszonális kapcsolatokat gyengító - ördögi körnek az egyik lehetséges leállítási módja, ha a sérelemre megbocsátással reagál a személy. Bár a megbocsátás eszménye már évszázadok óta fellelhetố a vallások tanításában (McCullough és Worthington 1999), a pszichológia csak a 20. század utolsó két évtizedében kezdte el vizsgálni ezt a témát. A feltámadt érdeklődést jól illusztrálja az alábbi idézet:

"Szemben azzal, amit sokan gondolnak, a megbocsátás nem egy misztikus és fennkölt idea, amit a zsidó-keresztény kultúrkör néhány ezer évének köszönhetünk. Eredetét nem az emberek elméjében kell keresnünk, éppen ezért nem sajátíthatja ki egyetlen ideológia vagy vallás sem. Az a tény, hogy a majmok, emberszabású majmok és az emberek mind mutatják a megbocsátást, azt jelenti, hogy valószínúleg már több, mint 30 millió éves, és megelózi ezen primáták evolúciós szétválását... Ahelyett, hogy a megbocsátást az ösztönök feletti gyózelemnek tekintenénk, a benne megjelenô pszichológiai mechanizmusok gyökereit és univerzalitását kell tanulmányozni. Itt az idő, hogy a tudomány megjelenjen a színen" (de Waal 1989, 270).

Az elmúlt néhány évben számos cikket, kutatást inspirált a megbocsátás konstruktuma, az eredményeket konferenciákon és kézikönyvekben (McCullough és mtsai 2000) mutatják be a szerzók. Ez a fejlemény egy új pszichológiai paradigma, az ún. „pozitív pszichológia” megjelenéséhez köthetô. A pozitív pszichológia képviselói a II. világháború utáni pszichológiát „viktimológizálódott” tudománynak tekintik, mivel elsôsorban a szenvedéssel és annak gyógyításával foglalkozott (Seligman és Csíkszentmihályi 2000). Az új megközelítés képviselói ezzel szemben az emberi erôsségekre és a fejlődés lehetôségére koncentrálnak. Ebbe a gondolatkörbe kapcsolódik a megbocsátás kutatása is.

\footnotetext{
${ }^{1}$ Cikkünkben „áldozat”-nak, illetve „elkövető”-nek nevezzük az interperszonális konfliktus résztvevőit, függetlenül a szavak büntetójogi jelentésétól.
} 
Cikkünkben a megbocsátás definiálása után áttekintjük, hogy milyen tényezők állnak a megbocsátás hátterében. Ezután a megbocsátás hatásait, majd a megbocsátást segító intervenciós technikákat vesszük sorra.

\section{A MEGBOCSÁTÁS DEFINÍCIÓI}

A megbocsátást meg kell különböztetni a kegyelemtól (ami jogi fogalom), az elnézéstôl (ami magában foglalja a tett igazolását), a mentség kereséstól (ami azt implikálná, hogy enyhítő körülmények vezettek a tetthez), a felejtéstól (ami a sérelemre vonatkozó emléknyom elhalványulását jelenti), és a tagadástól (ami arra vonatkozik, hogy a személy nem tud vagy nem akar szembenézni az ót ért sérelmekkel) (McCullough és Witvliet 2002). A legtöbb kutató egyetért azzal, hogy a megbocsátás nem jelent egyet a kibéküléssel, ami egy sérült kapcsolat helyreállítására vonatkozik.

Megbocsátásnak az áldozat - elkövetôre irányuló - gondolataiban, érzelmeiben és/vagy viselkedésében bekövetkező proszociális változást nevezzük (McCullough és Witvliet 2002). Bár számos megbocsátás-definíció létezik, ezek egy dologban megegyeznek: amikor az emberek megbocsátanak, (érzelmi és kognitív) válaszaik azok irányába, akik megsértették óket, egyre pozitívabbá vállnak (McCullough és mtsai 2000).

Worthington és mtsai (2005) különbséget tesznek a döntési és az érzelmi megbocsátás között. A döntési megbocsátás esetében a személy tudatosan dönt arról, hogy megbocsát, nem keresi a bosszú lehetôségét. Ezen típusú megbocsátás megtörténhet a negatív érzelmek megszúnése nélkül is. Míg a döntési megbocsátás viszonylag gyorsan megtörténhet, addig az érzelmi megbocsátás kialakulása hosszabb időt igényel. Ebben az esetben a tettesre vonatkozó érzelmekben és motívumokban történik változás. Az olyan érzések, mint a hála a múltbéli helyzetekért, ahol bocsánatot nyertünk, az alázatosság, illetve a remény, segíthetik az érzelmi megbocsátás kialakulását.

Különbséget kell tennünk a megbocsátás mint vonás és mint válasz közt. Az elsô egy stabil diszpozíció (vonás, trait), a második egy egyszeri proszociális változás (állapot, state) a személy érzelmeiben, motivációjában és viselkedésében (McCullough és Witvliet 2002).

Utolsó dimenzióként említsük meg, hogy a megbocsátás lehet intraperszonális jellegú és interperszonális jellegú. Az elsố esetben a személyen belüli érzelmi, motivációs változásokban, a második esetben a kapcsolatban történt változásokon van a hangsúly. 


\section{A MEGBOCSÁTÁs MÉRÉSE}

Az elmúlt években számos méróeszközt fejlesztettek ki a megbocsátás mérésére. Ezek legtöbbje önbeszámolós teszt (1. táblázat).

1. táblázat. A megbocsátás mérésére szolgáló leggyakrabban használt skálák

\begin{tabular}{|l|l|}
\hline \multicolumn{1}{|c|}{ Méróeszköz } & \multicolumn{1}{|c|}{ A méróeszköz ismertetése } \\
\hline Enright Forgiveness Inventory & Subkoviak és mtsai (1995) \\
Forgiveness Scale & Wade (1989) \\
Transgression - Related Interpersonal & McCullough és mtsai (1998) \\
$\quad$ Motivations Inventory & \\
Transgression Narrative Test of Forgivingness & Berry és mtsai (2001) \\
Trait Forgiveness Scale & Berry és mtsai (2000) \\
Forgiveness Likelihood Scale & Rye és mtsai (1999) \\
Multidimensional Forgiveness Inventory & Tangney és mtsai (1999) \\
\hline
\end{tabular}

A 60 tételes Enright Forgiveness Inventory (Subkoviak és mtsai 1995) 6 alskálából áll, melyek a sérelem áldozatának - az elkövetóre irányuló pozitív, illetve negatív érzelmeit, gondolatait és viselkedési szándékait mérik. A McCullough és mtsai (1998) által kidolgozott Transgression Related Interpersonal Motivations Inventory (TRIM Inventory) két alskálát tartalmaz: az elsố azt méri, hogy az áldozat milyen mértékben motivált az elkövetó elkerülésére (Elkerülés faktor), a második azt, hogy mennyire motivált a bosszúra (Bosszú faktor). A Transgression Narrative Test of Forgivingness (Berry és mtsai 2001) 5 hipotetikus helyzetet ír le, és a vizsgált személyeknek azt kell eldönteniük, hogy milyen valószínúséggel bocsátanának meg az egyes helyzetekben. Rye és mtsai (1999) Forgiveness Likelihood Scale-je hasonló módszert alkalmazva szembesíti a személyeket 15 elképzelt helyzettel (pl. egy családtag megalázza a személyt; betörnek a személy lakásába és ellopják a pénzét). A Multidimensional Forgiveness Inventory (Tangney és mtsai 1999) 16 helyzetet ír le, melyekben a vizsgált személynek hol az áldozat, hol az elkövetó nézópontját kell felvennie. Elkövetóként azt kell megbecsülniük, hogy milyen valószínúséggel keresnének megbocsátást, illetve milyen valószínúséggel bocsátanának meg maguknak, sértettként pedig azt, hogy milyen valószínúséggel bocsátanának meg.

A megbocsátást mérő legtöbb skála erős belső konzisztenciát, megfelelô konvergens és divergens validitást mutat. A kérdőíves módszerek mellett egy interjú módszert is kidolgoztak a megbocsátás mérésére (Enright és mtsai 1989). Itt a megbocsátással kapcsolatos morális - kognitív fejlődés szintjét (ld. alább) mérik. 


\section{A MEGBOCSÁTÁs GYÖKEREI}

A megbocsátás hátterében álló tényezók közül a kognitív fejlődés szintjét, a fóbb személyiségvonásokat, a szociális faktorokat és egy hipotetikus biológiai modellt tekintünk át.

\section{Kognitív fejlódés}

A megbocsátásra való képesség összefügg az életkorral: ahogy idősebbekké válunk, egyre motiváltabbak leszünk a megbocsátásra (Mullet és Girard 2000; Park és Enright 1997). Enright és mtsai (1994) szerint ennek hátterében a kognitív fejlődés áll, és ez a fejlődési folyamat párhuzamba állítható a moralitás Kohlberg (1976) által leírt szakaszaival. Ennek megfelelően azok, akik a megbocsátásra vonatkozó morális érvelés legalsó szintjén - a bosszúálló megbocsátás, illetve a restituáló megbocsátás szintjén helyezkednek el, úgy érvelnek, hogy a megbocsátás csak akkor helyénvaló, ha a sértett már bosszút állt, illetve ha az elkövetó már jóvátette tettét. A középsó szinten - az elvárt megbocsátás és a törvényesen elvárt megbocsátás szintjén - a személy úgy érzi, hogy a megbocsátás a szociális, morális vagy vallási normák, szabályok miatt szükséges. A legmagasabb szinteken - megbocsátás mint társas harmónia és megbocsátás mint szeretet - a személy úgy érzi, hogy a megbocsátás azért megfeleló válasz, mert hozzájárul a szociális harmóniához, illetve mert rajta keresztül kifejezôdhet a feltétel nélküli szeretet.

\section{Személyiségvonások}

A megbocsátásra hajlamos emberek számos személyiségvonás mentén különböznek a megbocsátásra kevésbé hajló személyektól. A megbocsátó emberek alacsonyabb szorongással és ellenségességgel jellemezhetóek (Mauger és mtsai 1996). Kevésbé ruminálnak (Metts és Cupach 1998) és kevésbé nárcisztikusak (Davidson 1993; Brown 2004). Maltby és Day (2004) megbocsátó és kevésbe megbocsátó személyek preferált elhárítási módjait vetette össze. Az eredmények szerint a megbocsátásra kevésbé hajlamos személyek sokkal nagyobb valószínúséggel alkalmaznak neurotikus elhárítási mechanizmusokat, mint a megbocsátó személyek.

Számos kutatás alapján azt mondhatjuk, hogy a Big Five vonások közül a neuroticizmus negatív, a barátságosság pozitív kapcsolatban áll a megbocsátással (Ashton és mtsai 1998; Brose és mtsai 2005). Brose és mtsai 
(2005) ezenkívül azt találták, hogy a lelkiismeretesség csökkenti a megbocsátás valószínúségét.

\section{Szociális faktorok}

A megbocsátás valószínúségét nagymértékben növeli, ha az elkövetó bocsánatot kér, illetve megbocsátást keres (McCullough és mtsai 1997, 1998). Ennek hátterében elsôsorban az elkövetô iránti negatív érzelmek csökkenése és a felé megnyilvánuló empátia erôsödése áll.

A megbocsátás valószínúségét befolyásolja, hogy milyen minőségú a kapcsolat az áldozat és az elkövetó között: valószínúbb a megbocsátás, ha köztük a kapcsolat közeli és érzelmileg kielégító. Finkel és mtsai (2002) azt vizsgálták, hogy párkapcsolatban éló személyek hogyan reagálnak partnerük hútlenségére. Eredményeik szerint az elkötelezódés szintje jól bejósolta a megbocsátás valószínúségét. Az elköteleződés és megbocsátás közti kapcsolatot a hútlenség kognitív értelmezése közvetítette. Hoyt és mtsai (2005) a családi konfliktusokkal kapcsolatos megbocsátással összefüggésben azt találták, hogy a kapcsolattal való elégedettség elsősorban a nóknél befolyásolta a megbocsátás valószínúségét. Ezzel szemben a férfiaknál diszpozicionális hatások befolyásolták a megbocsátást.

\section{Neurológiai háttér}

A neurális képalkotó eljárások segítenek feltárni azokat az agyterületeket, melyek a megbocsátó, illetve nem megbocsátó személyek agyában aktiválódnak. Megbocsátás hiányában ugyanazok a területek aktiválódnak, melyek stresszhelyzetben, düh vagy agresszió esetén (Pietrini és mtsai 2000). Farrow és mtsai (2001) MRI technika segítségével talált nagyfokú átfedést az empátia és a megbocsátás során aktiválódott agyterületek közt (az átfedés azonban nem tökéletes, tehát két különbözó konstruktumról van szó).

Clark (2005) hipotetikus modelljében a megbocsátás hátterében álló neurológiai tényezóket próbálja feltárni. Modellje szerint a sérelemmel járó érzelmi hatás egyszerre aktiválja a hippokampuszt (amely az emléknyom rögzítésért felel) és az amygdalát (mely az érzelmi élményért felel). Minél súlyosabb a sérelem, annál „mélyebb” lesz az érzelmi emléknyom. Eme kapcsolat kialakulása után az emléknyom aktiválódása az amygdalán keresztül a szimpatikus idegrendszer múködésének fokozódásához vezet - ez pedig a "harcolj vagy menekülj” válaszra készíti fel a szervezetet. Ezzel párhuzamosan emelkedik az érzelmi arousal szintje, ami például dühben nyilvánulhat meg. 
Clark (2005) szerint a megbocsátás hátterében ennek az idegrendszeri mintázatnak a megszakítása áll. A személy tudatos - megbocsátásra vonatkozó - érvelése, gondolatai hatására a sérelem emlékének felidézése már nem aktiválja az amygdalát. A modell szerint ennek következtében a szimpatikus aktivitás csökkenése, a „harcolj vagy menekülj” válasz ${ }^{2}$ és az ezzel összefüggő izomfeszültség gyengülése valószínúsíthetô. Clark modelljének empirikus tesztelése még várat magára.

\section{A MEGBOCSÁTÁS HATÁSAI}

A megbocsátás aktusa mind a megbocsátó, mind pedig a „megbocsátást nyeró" személyre hatást gyakorol. Ez a hatás kimutatható fiziológiai, biológiai, illetve mentális szinten. Ezen hatások áttekintése után lehetséges közvetítóként a megbocsátást mint coping választ elemezzük.

\section{A megbocsátás fizikai egészségre kifejtett hatása}

A megbocsátás és a fizikai egészség közti kapcsolat jól dokumentált (McCullough 2000). A témában végzett kutatások nagy része a megbocsátás hiányának (illetve ennek egyik megnyilvánulási formájának, az ellenségességnek) a hatását mérték az egészségi állapotra. Az ellenségesség számos kutatás szerint megnöveli a kardiovaszkuláris múködési problémák valószínúségét (Miller és mtsai 1996). A megbocsátás hiánya ugyanolyan hormonális változásokkal jár, melyek általában stresszhelyzetben figyelhetók meg. Berry és Worthington (2001) szerint a megbocsátás hiányára vonatkozó hajlam a nyál magasabb kortizolszintjével és magasabb kortizol-reaktivitással társul. Seybold és mtsai (2001) veteránokat vizsgálva mutatták ki, hogy a megbocsátásra „krónikusan” képtelen személyek vérképe nagymértékben hasonlított a krónikus stressznek kitett személyekéhez. A megbocsátó személyek jobb egészségmagatartásról, alacsonyabb szorongás- és depressziószintról számoltak be.

A megbocsátás csökkenti a szem körüli izmok feszültségi állapotát, a galvános bórreakció mértékét és a szívritmust (Witvilet és mtsai 2001). Ezenkívül alacsonyabb szisztolés és diasztolés vérnyomás, illetve alacsonyabb kardiovaszkuláris reaktivitás társul hozzá (Lawler és mtsai 2003). Witvliet és mtsai (2002) a megbocsátást elnyerố személy érzelmi állapo-

\footnotetext{
${ }^{2}$ Feltételezhető, hogy ezzel párhuzamosan erősödik az „oltalmazó - gondoskodó” (“ten-
} ding - befriending") stresszválasz (Taylor és mtsai 2000). 
tát vizsgálták. Ezen személyeknél a mosoly gyakorisága nôtt, a szemöldökráncolás gyakorisága csökkent.

\section{A megbocsátás mentális egészségre gyakorolt hatása}

A megbocsátás legtöbb önbeszámolós méróeszköze pozitívan korrelál a mentális egészség mutatóival. Toussaint és Webb (2005) áttekintó tanulmánya szerint a megbocsátás csökkenti a szorongás, a depresszió és a düh szintjét (Subkoviak és mtsai 1995; Witvliet és mtsai 2001). Trauma vagy abúzus átélése után a megbocsátás csökkentheti a poszttraumás tünetek megjelenését. Kaminer és mtsai (2001) 134 súlyos - az alapvetó emberi jogokat sértő - sérelmet átélt személynél vizsgálták a megbocsátás és a mentális problémák kapcsolatát. A vizsgálati személyek $63 \%$-a rendelkezett pszichiátriai diagnózissal - közülük legtöbben a depresszió (55\%) és a poszttraumás stressz betegség (42\%) tüneteit mutatták. Az eredmények szerint a legalacsonyabb megbocsátásszinttel jellemezhetô személyek közt sokkal magasabb volt a pszichiátriai problémák aránya. Friedberg és mtsai (2005) New York-i vizsgálati személyeinél azt vizsgálta, hogy a megbocsátás, illetve a ruminálásra való hajlam hogyan befolyásolja a 2001. szeptember 11-i terrortámadásra vonatkozó stressz-szintet és a traumatizálódás mértékét. A megbocsátás alacsony szintje magasabb stressz-szintet jósolt be, és ezt a hatást a ruminálásra vonatkozó hajlam közvetítette.

Megemlítendó, hogy a fenti eredmények keresztmetszeti kutatásokban születtek, ezért csak korlátozottan alkalmasak oksági kapcsolatok leírására. A longitudinális vizsgálatok eddig még nem erósítették meg a megbocsátás mentális egészségre gyakorolt pozitív hatását (McCullough és mtsai 2001).

\section{Megbocsátás és fizikai-mentális egészség: lehetséges közvetítók}

Az eddigiek során konzisztens kapcsolat rajzolódott ki a megbocsátás és a fizikai-mentális egészség között. Ezt a kapcsolatot több modell próbálja értelmezni.

Smith (1992) 6 lehetséges közvetítő tényezőt ír le: (1) csökkent pszichofiziológiás reaktivitás, (2) csökkent interperszonális stressz-szint, (3) a stressz gyakoriságának csökkenése, (4) az ellenségesség káros hatásainak csökkenése, (5) az egészségmagatartás erôsödése és végül (6) a transzcendens, illetve vallásos aspektusok erósödése. Thoresen és mtsai (2000) 
szintén 6 lehetséges utat különítenek el: (1) a krónikus hibáztatás, düh és ellenségesség csökkenése, (2) a krónikusan magas arousal, illetve az allosztatikus terhelés csökkenése, (3) optimista gondolkodás, (4) az egészségvédố magatartásra vonatkozó énhatékonyság erôsödése, (5) társas támogatás és a (6) transzcendens tudatosság fokozódása.

Lawler és mtsai (2005) modellje 4 tényezốt hangsúlyoz. A spiritualitás a transzcendencia élményen keresztül támogathatja az egészséget. ${ }^{3}$ A második tényezó a negatív érzelmek (depresszió, szorongás, harag) csökkenése, ami szoros kapcsolatban áll az egészségi állapottal. A megbocsátás szociális készségként is értelmezhetô, mivel hozzájárul a kapcsolatok fenntartásához. A szociális támogatás és az egészségi állapot közti pozitív kapcsolat jól dokumentált (Brownley és mtsai 1996). Az utolsó tényezó a stressz-szint csökkenése, ami szintén szoros kapcsolatban áll az egészségi állapottal. Végezetül vizsgáljuk meg a Worthington és Scherer (2004) által leírt tényezóket (2. táblázat).

Worthington és Scherer (2004) a közvetlen hatások közé sorolja az egészségkárosító ellenségesség csökkentését, az immunfunkciók javítását (a citokin- és kortizoltermelés csökkentésén és az antitesttermelés növelésén keresztül).

Ezenkívül kapcsolatot tételeznek fel a megbocsátás és három központi idegrendszeri folyamat - (1) a Gray (1994) által leírt motivációs rendszerek múködése, (2) a hipotalamusz tesztoszteron- és szerotonintermelése és (3) a vagus tónus - között. Gray (1994) két motivációs rendszert azonosított. A Viselkedés Gátló Rendszer (Behavioral Inhibition System, BIS) averzív vagy új ingerek hatására aktiválódik és az arousal növekedéséhez, illetve az aktuális viselkedés gátlásához vezet. A Viselkedés Aktiváló Rendszert (Behavioral Activation System, BAS) mind pozitív (pl. boldogság), mind negatív érzelmek (pl. harag, düh) aktiválják. Aktivitása a környezet felé forduláshoz és aktív megküzdéshez vezet (HarmonJones és mtsai 2002). Worthington és Scherer (2004) szerint az aktív érzelem-fókuszú megküzdésként értelmezhetô megbocsátás (lásd alább) elsôsorban azokra lehet jellemzó, akik intenzíven múködő Viselkedés Aktiváló Rendszerrel bírnak. A Viselkedés Gátló Rendszer magas aktivitása hatására a személy „beleragadhat” a meg nem bocsátásba, és szorongást érezhet a jövóbeli potenciális interperszonális sérelmek miatt.

A második hipotetikus út a hipotalamusz tesztoszteron- és szerotonintermelésén keresztül „vezet”. A tesztoszteron növeli, a szerotonin csökkenti az agresszív viselkedést (a hipotalamusz gazdag mind a tesztoszteron-, mind a szerotonin-receptorokban, így ez a folyamat ide lokali-

\footnotetext{
${ }^{3}$ A spiritualitás, vallás és egészség kapcsolatáról lásd Plante és Sherman (2001).
} 
2. táblázat. A megbocsátás és a fizikai egészségi állapot közti közvetlen és közvetett hatások Worthington és Scherer (2004) alapján (A *-al jelölt hatások még nem bizonyítottak)

\begin{tabular}{|c|c|c|c|}
\hline & A megbocsátás... & $\begin{array}{c}\text { A megbocsátás hiányának } \\
\text { hatása }\end{array}$ & A megbocsátás hatása \\
\hline \multirow{5}{*}{ 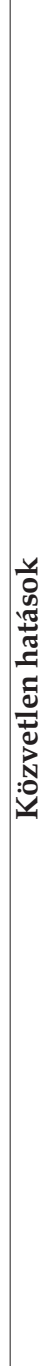 } & $\begin{array}{l}\text { 1. ... csökkenti az ellensé- } \\
\text { gességet. }\end{array}$ & $\begin{array}{l}\text { A megbocsátás hiányához } \\
\text { sokszor csatlakozó ellensé- } \\
\text { gesség számos (elsósorban } \\
\text { a kardiovaszkuláris rend- } \\
\text { szert érintố) egészségügyi } \\
\text { problémához kapcsolódik } \\
\text { (Williams és Williams 1993). }\end{array}$ & $\begin{array}{l}\text { A megbocsátás csökkenti } \\
\text { az ellenségességet (Al- } \\
\text { Mabuk és mtsai 1995) és a } \\
\text { hozzá kapcsolódó egész- } \\
\text { ségügyi veszélyeket. }\end{array}$ \\
\hline & $\begin{array}{l}\text { 2. ... befolyásolja az } \\
\text { immunrendszert a citokin- } \\
\text { rendszeren keresztül. }\end{array}$ & $\begin{array}{l}\text { A megbocsátás hiányához } \\
\text { kapcsolódó negatív érzel- } \\
\text { mek (elsősorban a citokin- } \\
\text { rendszeren keresztül) im- } \\
\text { munszupresszív hatásúak. } \\
\text { (Kiecolt-Glaser és mtsai 2002). }\end{array}$ & $\begin{array}{l}\text { Feltételezhetó, hogy a } \\
\text { megbocsátás befolyásolja } \\
\text { a citokintermelést.* }\end{array}$ \\
\hline & $\begin{array}{l}\text { 3. ... befolyásolja az } \\
\text { immunrendszert neuro- } \\
\text { endokrin hatásokon } \\
\text { keresztül. }\end{array}$ & $\begin{array}{l}\text { A megbocsátás hiánya ser- } \\
\text { kenti a HPA-tengely múkö- } \\
\text { dését és ezáltal a kortizol- } \\
\text { termelést (Berry és Wor- } \\
\text { thington 2001). }\end{array}$ & $\begin{array}{l}\text { Feltételezhetô, hogy a } \\
\text { megbocsátás csökkenti a } \\
\text { HPA-tengely aktivitását és } \\
\text { így a kortizoltermelést.* }\end{array}$ \\
\hline & $\begin{array}{l}\text { 4. ... befolyásolja az } \\
\text { immunrendszert az } \\
\text { antitesttermelésen } \\
\text { keresztül. }\end{array}$ & $\begin{array}{l}\text { A megbocsátás hiányához } \\
\text { társuló negatív érzelmek, } \\
\text { illetve stresszhelyzet hatá- } \\
\text { sára csökken az antitest- } \\
\text { termelés (Salovey és mtsai } \\
\text { 2000). }\end{array}$ & $\begin{array}{l}\text { Feltételezhető, hogy a } \\
\text { megbocsátás megakadá- } \\
\text { lyozza az antitesttermelés } \\
\text { csökkenését.* }\end{array}$ \\
\hline & $\begin{array}{l}\text { 5. ... befolyásolja a } \\
\text { központi idegrendszeri } \\
\text { folyamatokat. }\end{array}$ & $\begin{array}{l}\text { A megbocsátás, illetve an- } \\
\text { nak hiánya összefügghet a } \\
\text { BIS-BAS rendszer múkö- } \\
\text { désével, a tesztoszteron- és } \\
\text { szerotonintermeléssel, illet- } \\
\text { ve a vagus tónussal (lásd a } \\
\text { tanulmány szövegében). }\end{array}$ & $\begin{array}{l}\text { Lásd a tanulmány szöve- } \\
\text { gében. }\end{array}$ \\
\hline
\end{tabular}




\begin{tabular}{|c|c|c|c|}
\hline & A megbocsátás... & $\begin{array}{c}\text { A megbocsátás hiányának } \\
\text { hatása }\end{array}$ & A megbocsátás hatása \\
\hline \multirow{4}{*}{ 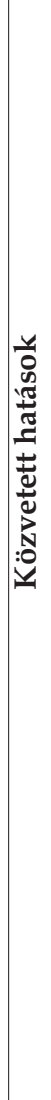 } & $\begin{array}{l}\text { 6. ... növeli a társas } \\
\text { támogatás mértékét. }\end{array}$ & - & $\begin{array}{l}\text { A megbocsátás szélesebb } \\
\text { körú és érzelmileg } \\
\text { kielégítóbb társas kapcso- } \\
\text { lattal jár, ami jobb egész- } \\
\text { ségi állapottal társul (pl. } \\
\text { Brownley és mtsai 1996). }\end{array}$ \\
\hline & $\begin{array}{l}\text { 7. ... csökkenti a házassá- } \\
\text { gok konfliktusosságát. }\end{array}$ & - & $\begin{array}{l}\text { A megbocsátás csökkenti } \\
\text { a házassági konfliktusok } \\
\text { gyakoriságát (Fincham és } \\
\text { mtsai 2002). A házasság } \\
\text { minósége szorosan } \\
\text { kapcsolódik az egészségi } \\
\text { állapothoz (Friedman és } \\
\text { mtsai 1995). }\end{array}$ \\
\hline & $\begin{array}{l}\text { 8. ... az egészséghez } \\
\text { kapcsolódó személyiség- } \\
\text { vonásokhoz kapcsolódik. }\end{array}$ & - & $\begin{array}{l}\text { A megbocsátás számos - } \\
\text { az egészséghez kapcsoló- } \\
\text { dó - személyiségvonáshoz } \\
\text { társul: ilyenek a vallásos } \\
\text { elköteleződés, a magas } \\
\text { empátia, alacsony rumi- } \\
\text { nálás és neuroticizmus. }\end{array}$ \\
\hline & $\begin{array}{l}\text { 9. ... jobb szociális készsé- } \\
\text { gekhez kapcsolódik. }\end{array}$ & - & $\begin{array}{l}\text { A megküzdés hatéko- } \\
\text { nyabb konfliktuskezelési } \\
\text { módszerekhez kapcso- } \\
\text { lódik. }\end{array}$ \\
\hline
\end{tabular}

zálható). Feltételezhetó, hogy a megbocsátás a szerotonintermelés serkentésén keresztül gátolja a tesztoszterontermelést.

A vagus gátló hatást fejt ki a szimpatikus idegrendszerre és így csökkenti az arousalt. Stresszor jelenlétében a vagus tónus csökken, ennek hatására hirtelen megemelkedik az arousal szintje. A vagus tónus alacsony szintje veszélyeztetố tényezô a kardiovaszkuláris megbetegedések szempontjából. Feltételezhetó, hogy a megbocsátó emberek magas vagus tónussal bírnak, így interperszonális fenyegetés esetén lassabb és kevésbé intenzív választ adnak. A fenti 3 hipotetikus összefüggés bizonyítása még jövóbeli kutatásokra vár.

A közvetett utak elsősorban a szociális kapcsolatok egészségvédő hatásán keresztül hatnak. A megbocsátás növeli a társas támogatottság mértékét, csökkenti a házassági konfliktusok gyakoriságát és sikeresebb 
konfliktuskezeló módszerekhez kapcsolódik. Ezenkívül számos olyan személyiségvonás (pl. vallásos elkötelezódés, alacsony neuroticizmus, magas barátságosság, alacsony ruminálás) kapcsolódik a megbocsátáshoz, melyek egészségvédô hatása jól dokumentált.

\section{ÖSSZEGZÉS: A MEGBOCSÁTÁS MINT MEGKÜZDÉSI FORMA}

Worthington és Scherer (2004) azt feltételezik, hogy a megbocsátás hiánya a negatív érzelmek olyan kombinációja, mely mind a fizikai, mind a mentális egészségre károsan hathat. Ennek a stresszortényezőnek a csökkentésére az emberek számos módszert alkalmazhatnak. Megpróbálhatják helyreállítani az igazságosságnak ítélt állapotot bosszú segítségével, bocsánatkérést vagy jóvátételt követelhetnek. A sérelemmel kapcsolatban uj értelmezési keret is alkotható (pl. jogosnak lehet a sérelmet tekinteni). A megbocsátás hiánya csökkenthető a helyzet elfogadásával, illetve olyan védekezések alkalmazásával, mint pl. a tagadás. A szerzók szerint a megbocsátás is egy ilyen módszer. Elképzelésük szerint az érzelmi megbocsátás (de nem a döntési megbocsátás!) az érzelem-fókuszú megküzdés egyik formájának tekinthetó, mely csökkenti a megbocsátás hiányából fakadó stresszválaszt. Hatására csökken a szimpatikus idegrendszer - a sérelem következtében bekövetkező - aktivitásnövekedése, csökken a negatív érzelmek (harag, feszültség, ellenségesség, félelem) szintje és a fizikai - mentális problémák valószínúsége.

\section{A MEGBOCSÁTÁST ELŐSEGÍTÓ INTERVENCIÓS TECHNIKÁK}

Számos kutatócsoport dolgozott ki intervenciós technikát a megbocsátás elősegítésére. Ezek egy része specifikus sérelmek (válás, inceszt, párkapcsolati problémák) megbocsátását célozza, más részük bármilyen sérelem esetén alkalmazható (Baskin és Enright 2004). Ezen módszerek legtöbbje nem egyéni, hanem csoportos foglalkozások keretén belül alkalmazható.

Az intervenciós programok két kutatócsoport köré csoportosíthatóak. Az Enright-csoport (Hebl és Enright 1993; Enright és Fitzgibbons 2000) egy 17 - majd késóbb 20 - lépésból álló programot dolgozott ki, mely kognitív, érzelmi és viselkedéses elemeket egyaránt magába foglal. A Worthington-csoport McCullough és Worthington (1995; McCullough és 
mtsai 1997) munkái alapján kidolgozta a megbocsátás REACH modelljét. A mozaikszó a technika egyes lépéseire utal. Az elsó lépés a sérelem felidézése (recall, R), ezután empátiát (empathy, E) kísérelnek meg kiépíteni az elkövetôvel szemben. A harmadik lépés a megbocsátás altruista (A) „odaajándékozása”. Végül a személyek nyilvánosan elköteleződnek (commit, C) a megbocsátás mellett és megpróbálnak kitartani (holding, H) mellette.

Wade és Worthington (2005) a megbocsátást támogató intervenciós technikák közös elemeit próbálta feltárni. Áttekintésükben 6 olyan elemet találtak, mely minden intervenciós technikában fellelhetô (3. táblázat).

Az intervenciós technikák elsố fontos összetevôje a megbocsátás definiálása, illetve leírása. Ez legtöbbször úgy történik, hogy a résztvevók megosztják egymással a megbocsátás jelentésére és a megbocsátás következményeire vonatkozó gondolataikat. A definíció hiányában a résztvevők félreérthetik a megbocsátás fogalmát, ami nemkívánatos hatásokhoz vezethet. Az a személy például, aki nem különíti el a megbocsátást (ami a gondolatokban, érzelmekben és motivációban bekövetkezó változás) és a kibékülést (azaz egy kapcsolat helyreállítását), az nehezen látja be, hogy megbocsátás lehetséges kibékülés, a kapcsolat folytatása nélkül is. Miután elkülöníti a két fogalmat, arra is képes lesz, hogy a megbocsátás tényétól függetlenül, racionális döntést hozzon a kapcsolat folytatásáról.

3. táblázat. A megbocsátást elősegítố intervenciós technikák közös összetevôi és néhány példa a használt módszerekre Wade és Worthington (2005) alapján

\begin{tabular}{|l|l|}
\hline \multicolumn{1}{|c|}{ Összetevő } & \multicolumn{1}{c|}{ Lehetséges technikák } \\
\hline 1. A megbocsátás definiálása & $\begin{array}{l}\text { - kétszemélyes vagy csoport-helyzetben } \\
\text { beszélgetés a megbocsátás jelentéséról }\end{array}$ \\
\hline 2. A sérelem felidézése & $\begin{array}{l}\text { - a sérelem részletes elmesélése } \\
\text { a csoportnak } \\
\text { - levélírás a sérelmet elkövetônek, } \\
\text { melyben pontosan leírjuk, hogyan éltük } \\
\text { meg a történteket }\end{array}$ \\
\hline 3. Empátia kialakítása & - fókuszálás az elkövetó nézópontjára \\
\hline 4. Mások kárára elkövetett saját & $\begin{array}{l}\text { "sérelemlista” kitöltése arról, hogy kit } \\
\text { hogyan bántottunk meg }\end{array}$ \\
\hline 5. Elkötelezódés a megbocsátás mellett & $\begin{array}{l}\text { - az elkötelezódés elónyeinek } \\
\text { és hátrányainak megbeszélése } \\
\text { - „megbocsátó” levél írása az elkövetónek }\end{array}$ \\
\hline 6. A megbocsátás hiányának leküzdése & $\begin{array}{l}\text { - a megbocsátás hiányából fakadó negatív } \\
\text { érzések elemzése, értelmezése } \\
\text { - az értelmezési keret megváltoztatása }\end{array}$ \\
\hline
\end{tabular}


Második lépésként a résztvevók felidézik az átélt sérelmet. A csoport megértő, támogató légkörében a terapeuta arra bátorítja a résztvevőket, hogy minél részletesebben számoljanak be arról, hogy mi történt velük. Minden intervenciós technikában közös pontnak túnik, hogy a terapeuta elfogadja az elmondottak valódiságát, annak igazságtalan voltát és a páciens negatív érzelmeinek helyénvalóságát, jogosságát. A sérelem felidézése hozzájárul a további lépések hatékonyságához, erôsíti a bizalom érzését és a terápiás szövetséget. A negatív érzések felidézése önmagában is terápiás hatással bírhat (Pennebaker és Seagal 1999).

A harmadik közös elem az empátia kialakítása. A résztvevóket arra bátorítják, hogy vegyék fel az elkövetó nézőpontját, és empatikusan próbálják megérteni, hogy mi vezetett a tettéhez. Elsősorban arra fókuszálnak, hogy a sérelem elkövetése elótt, illetve közben milyen gondolatai, érzései lehettek. Abban az esetben, ha a sérelem, az elkövetett tett különösen kegyetlen és értelmetlennek túnő, az elkövetôvel való empatizálás igen nehéz feladat, sôt bizonyos kritikák szerint „haszontalan mentális és érzelmi gimnasztika" (Wade és Worthington 2005, 167).

A következó - elsôre talán paradoxonnak túnó - összetevô a mások kárára elkövetett saját tettek elismerése. Ekkor a terapeuta arra bátorítja a résztvevóket, hogy idézzenek fel olyan eseteket, amikor sérelmet okoztak másoknak, megbocsátást kerestek és megbocsátást nyertek. Ez a lépés segít a megbocsátást gátló attribúciós torzítás („,Ha én követek el hibát, akkor csak a viselkedésemmel volt baj, ha te követsz el hibát, akkor veled, a személyiségeddel van a baj") leküzdésében, annak belátásában, hogy mi is esendóek vagyunk, és nem sokban különbözünk az elkövetótól, valamint annak felidézésében, hogy milyen érzés megbocsátást várni és megkapni azt.

Utolsó előtti lépésként a személy elkötelezi magát a megbocsátás mellett. Enright és munkacsoportja ezt az elköteleződést tudatos választásként konceptualizálja, míg a Wortington-csoport az elkötelezódés „nyilvános" jellegét hangsúlyozza. Az elköteleződés előtt a résztvevők megvitatják a megbocsátás lehetséges elónyeit és hátrányait, majd a terapeuta arra bátorítja óket, hogy „döntsenek a megbocsátás mellett”. Az elköteleződés tényét a legtöbb esetben írásban is rögzítik, vagy egy "szerződés" aláírásával, vagy az elkövetônek címzett levél megírásával (ezek a levelek nem feltétlenül kerülnek ténylegesen feladásra).

Végül igen sok technika foglalkozik a megbocsátás hiányának leküzdésével. Itt elsősorban a düh, bosszúvágy kontrolljáról, illetve a rumináló tendenciák kezeléséról van szó. A résztvevók összegyújthetik azokat a negatív következményeket, melyek a megbocsátás hiányából fakadnak. Ugyancsak használható a kognitív átértelmezés technikája, melynek so- 
rán a személyt arra bátorítják, hogy gondolja át, milyen előnyökhöz jutott a sérelemnek köszönhetôen. Ilyen elôny lehet például más szenvedók iránti empátia növekedése, az önismeret erôsödése és a „spirituális” értelemkeresés serkentése.

\section{Az intervenciós technikák hatásossága}

Worthington és mtsai (2000) metaanalízisükben 12 - megbocsátást serkentô - csoport hatékonyságát tekintette át. Eredményeik szerint ezek az intervenciók általában hatékonyan növelték a megbocsátásra való hajlandóságot. A 6 óránál hosszabb intervenciók hatékonyabbak voltak, mint az ennél rövidebb idótartalmúak.

Baskin és Enright (2004) az intervenciós technikákat aszerint sorolták két csoportba, hogy a döntési vagy az érzelmi megbocsátás elérését túzik ki célul. Áttekintésük szerint a döntési megbocsátást célzó technikák kisebb mértékben vezettek a megbocsátás pozitív mentális hatásaihoz (lásd fent), mint az érzelmi megbocsátást célzóak. Wade és mtsai (2005) metaanalízise szerint az intervenciós technikák empátia erôsítő összetevője jósolja be leginkább a technika hatékonyságát. Emellett fontos prediktív tényezőnek bizonyult a terápia idótartama, valamint a megbocsátást gátló tényezók feltárása.

\section{ÖSSZEFOGLALÁS}

Cikkünkben a megbocsátást olyan érzelem-fókuszú megküzdési stratégiaként értelmeztük, mely sikeresen megvéd az interperszonális konfliktusok káros fizikai és mentális hatásaitól. Ez a megküzdési forma bizonyos mértékig tanulható, illetve fejleszthetó. Egészségedukációs, illetve mentálhigiénés nézốpontból a megbocsátás képességének fejlesztése hasznos lehet mind a primer, szekunder, illetve tercier prevenció számára. Megakadályozhatja a stresszállapot kialakulását, csökkentheti a stresszor káros hatásait, illetve segíthet a rehabilitációban, reszocializációban. Speiers (2004) alapján azt mondhatjuk, hogy a megbocsátás sikeres szekunder prevenciós technika, mely segít megakadályozni, hogy különbözó sérelmeket átélóknél, búncselekmények áldozatainál további mentális problémák alakuljanak ki.

Mivel a megbocsátás-kutatás igen rövid múltra tekinthet vissza, még számos kérdés vár megválaszolásra. A témában végzett legtöbb kutatás keresztmetszeti jellegú volt, így ezek oksági hatások leírására csak korlátozottan alkalmasak. Az oksági kapcsolatok és a "harmadik változó” 
problémájának kiküszöböléséhez longitudinális vizsgálati elrendezésre van szükség. Tisztázásra vár, hogy a megbocsátás pozitív hatásai vajon a megbocsátás aktusának, vagy - az ennek nyomán kialakuló - pozitív érzelemnek köszönhetóek-e. Végül nem tisztázott, hogy milyen káros hatásai lehetnek a megbocsátásnak, és ezek hogyan védhetőek ki.

\section{Irodalom}

Al-Mabuk, R. H., Enright, R. D., Cardis, P. A. (1995): Forgiving education with parentally love-deprived late adolescents. Journal of Moral Education, 24: 427-444.

Ashton, M. C., Pauonen, S. V., Helmes, E., Jackson, D. N. (1998): Kin altruism, reciprocal altruism, and the Big Five personality factors. Evolution and Human Behavior, 19: 243255.

Aureli, F., Cozzolino, R., Cordisci, C., Scucchi, S. (1992): Kin-oriented redirection among Japanese macaques: an expression of a revenge system? Animal Behaviour, 44: 283291.

Baskin, T. W., Enright, R. D. (2004): Intervention studies on forgiveness: a meta-analysis. Journal of Counseling and Development, 82: 79-90.

Baumeister, R. F., Exline, J. J., Sommer, K. L. (1998): The victim role, grudge theory, and two dimensions of forgiveness. In Worthington, E. L. (ed.): Dimensions of Forgiveness: Psychological Research and Theological Perspectives. Templeton Foundation Press, Philadelphia, 79-104.

Berry, J. W., Worthington, E. L. (2001): Forgivingness, relationship quality, stress while imagining relationship events, and physical and mental health. Journal of Counsulting Psychology, 48: 447-455.

Berry, J. W., Worthington, E. L., Parrott, L., O'Connor, L. E., Wade, N. G. (2001): Dispositional forgivingness: Development and construct validity of the Transgression Narrative Test of Forgivingness (TNTF). Personality and Social Psychology Bulletin, 27: 12771290.

Brose, L. A., Rye, M. S., Lutz-Zois, C., Ross, S. R. (2005): Forgiveness and personality traits. Personality and Individual Differences, 39: 35-46.

Brown, R. P. (2004): Vengeance is mine: narcissism, vengeance, and the tendency to forgive. Journal of Research in Personality 38: 576-584.

Brownley, K. A., Light, K. C., Anderson, N. B. (1996): Social support and hostility interact to influence clinic, work, and home blood pressure in Black and White men and women. Psychophysiology, 33: 434-445.

Clark, A. J. (2005): Forgiveness: a neurological model. Medical Hypothesis, 65: 649-654.

Davidson, D. L. (1993): Forgiveness and narcissism: consistency in experience across real and hypothetical hurt situation. Dissertation Abstracts International, 54: 2746.

de Waal, F. (1989): Peacemaking among Primates. Harvard University Press, Cambridge.

de Waal, F. (1996): Good Natured: the Origins of Right and Wrong in Humans and Other Animals. Harvard University Press, Cambridge.

Enright, R. D., Fritzgibbons, R. P. (2000): Helping Clients Forgive: an Empirical Guide for Resolving Anger and Restoring Hope. American Psychological Association, Washington DC. 
Enright, R. D., Human Development Study Group (1994): Piaget on the moral development of forgiveness: identity or reciprocity? Journal of Moral Education, 21: 63-80.

Enright, R. D., Santos, M. J. D., Al-Mabuk, R. (1989): The adolescent as forgiver. Journal of Adolescence, 12: 99-110.

Farrow, T. F. D., Zheng, Y., Wilkinson, I. D. (2001): Investigating the functional anatomy of empathy and forgiveness. Neuroreport, 12: 2433-2438.

Fincham, F. D., Paleari, F. G., Regalia, C. (2002): Forgiveness in marriage: the role of relationship quality, attributions and empathy. Personal Relationships, 9: 27-37.

Finkel, E. J., Rusbult, C. E., Kumashiro, M., Hannon, P. A. (2002): Dealing with betrayal in close relationships: does commitment promote forgiveness? Journal of Personality and Social Psychology, 82: 956-974.

Friedberg, J. P., Adonis, M. N., von Bergen, H. A., Suchday, S. (2005): Short communication: September $11^{\text {th }}$ related stress and trauma in New Yorkers. Stress and Health, 21: 53-60.

Friedman, H. S., Tucker, J. S., Schwartz, J. E., Tomlinson-Keasey, C., Martin, L. R., Wingard, D. L., Criqui, M. H. (1995): Psychosocial and behavioral predictors of longevity: the aging and death of the "Termines". American Psychologist, 50: 69-78.

Gray, J. A. (1994): Personality dimensions and emotion systems. In Ekman, P., Davidson, R. J. (eds): The Nature of Emotions: Fundamental Questions. Oxford University Press, New York, 329-331.

Harmon-Jones, E., Abramson, L. Y., Sigelman, J., Bohling, A., Hogan, M. E., HarmonJones, C. (2002): Proneness to hypomania/mania symptoms or depression symptoms and asymmetrical frontal cortical responses to an anger-evoking event. Journal of Personality and Social Psychology, 82: 610-618.

Hebl, J. H., Enright, R. D. (1993): Forgiveness as a psychotherapeutic goal with elderly females. Psychotherapy, 30: 658-667.

Hoyt, W. T., McCullough, M. E., Fincham, F. D., Maio, G., Davilla, J. (2005): Responses to interpersonal transgressions in families: forgiveness, forgivability, and relationshipspecific effects. Journal of Personality and Social Psychology, 89: 375-394.

Kaminer, D., Stein, D. J., Mbanga, I., Zungu-Dirwayi, N. (2001): The Truth and Reconciliation Commission in South Africa: relation to psychiatric status and forgiveness among survivors of human right abuses. British Journal of Psychiatry, 178: 373-377.

Kiecolt-Glaser, J. K., McGuire, L., Robles, T. F., Glaser, R. (2002): Emotions, morbidity, and mortality: new perspectives from psychoneuroimmunology. Annual Review of Psychology, 53: 83-107.

Kohlberg, L. (1976): Moral stages and moralization: the cognitive-developmental approach. In Lickona, T. (ed.): Moral Development and Behavior. Holt, New York, 31-53.

Lawler, K. A., Younger, J. W., Piferi, R. L. (2003): A change of heart: cardiovascular correlates of forgiveness in response to interpersonal conflict. Journal of Behavioral Medicine, 26: 373-393.

Lawler, K. A., Younger, J. W., Piferi, R. L., Jobe, R. L., Edmondson, K. A., Jones, W. H. (2005): The unique effects of forgiveness on health: an exploration of pathways. Journal of Behavioral Medicine, 28: 157-167.

Maltby, J., Day, L. (2004): Forgiveness and defence style. Journal of Genetic Psychology, 165: 99-109.

Mauger, P.A., Saxon, A., Hamil, C., Pannell, M. (1996): The relationship of forgiveness to interpersonal behavior. A Southeastern Psychological Association éves gyúlésén tartott előadás. 
McCullough, M. E. (2000): Forgiveness as human strenght: conceptualization, measurement, and links to well-being. Journal of Personality and Social Psychology, 19: 43-55.

McCullough, M. E, Bellah, C. G., Kilpatrick, S. D., Johson, J. L. (2001): Vengefulness: relationships with forgiveness, rumination, well-being, and the Big Five. Personality and Social Psychology Bulletin, 27: 601-610.

McCullough, M. E., Pargament, K. I., Thoresen, C. T. (eds) (2000): Forgiveness: Theory, Research and Practice. Guilford, New York.

McCullough, M. E., Rachal, K. C., Sandage, S. J., Worthington, E. L., Brown, S. W., Hight, T. L. (1998): Interpersonal forgiving in close relationships. II. Theoretical elaboration and measurement. Journal of Personality and Social Psychology, 75: 1586-1603.

McCullough, M. E., Witvliet, C. V. O. (2002): The psychology of forgiveness. In Snyder, C. R., Lopez, S. J.: Handbook of Positive Psychology. Oxford University Press, New York, 446-457.

McCullough, M. E., Worthington, E. L. (1995): Prompting forgiveness: a comparison of two brief psycho - educational interventions with a waiting list control. Counselling and Values, 40: 55-68.

McCullough, M. E., Worthington, E. L. (1999): Religion and the forgiving personality. Journal of Personality, 67: 1141-1164.

McCullough, M. E., Worthington, E. L., Rachal, K. C. (1997): Interpersonal forgiving in close relationships. Journal of Personality and Social Psychology, 73: 321-336.

Metts, S., Cupach, W. R. (1998): Predictors of Forgiveness Following a Relational Transgression. A IX. International Conference on Personal Relationships, Saratoga Springs.

Miller, T. Q., Smith, T. W., Turner, C. V., Guijarro, M. L., Hallet, A. J. (1996): A metaanalytic review of research on hostility and physical health. Psychological Bulletin, 119: 322-348.

Mullet, E., Girard, M. (2000): Developmental and cognitive points of view on forgiveness. In McCullough, M. E., Pargament, K. I., Thorsen, C. E. (eds): Forgiveness: Theory, Research and Practice. Guilford. New York, 111-132.

Park, Y. O., Enright, R. D. (1997): The development of forgiveness in the context of adolescent friendship conflict in Korea. Journal of Adolescence, 20: 393-402.

Pennebaker, J. W., Seagal, J. D. (1999): Forming a story: the health benefits of narrative. Journal of Clinical Psychology, 55: 1234-1254.

Pietrini, P., Guazzelli, M., Basso, G., Jaffe, K., Grafman, J. (2000): Neural correlates of imaginal aggressive behavior assessed by positron emission tomography in healthy subjects. American Journal of Psychiatry, 157: 1772-1781.

Plante, T. G., Sherman, A. C. (2001): Faith and Health. Guilford Press, New York.

Reiss, S., Havercamp, S. M. (1998): Toward a comprehensive assessment of fundamental motivation: factor structure of the Reiss profiles. Psychological Assessment, 10: 97-106.

Rye, M. S., Loiacono, D., Kmett, C., Folck, C., Hovanscek, A., Olszewski, B., Martin, J., Madia, B., Danko,, S., Heim, T., Ryan, C. (1999): Evaluation of the psychometric properties of two forgiveness scales. Az American Psychological Association 107. konferenciáján bemutatott poszter.

Salovey, P., Rotham, A. J., Detweiler, J. B., Steward, W. T. (2000): Emotional states and physical health. American Psychologist, 55: 110-121.

Seligman, M. E. P., Csíkszentmihályi, M. (2000): Positive psychology: an introduction. American Psychologist, 55: 5-14.

Seybold, K. S., Hill, P. C., Neumann, J. K., Chi, D. S. (2001): Physiological and psychological correlates of forgiveness. Journal of Psychology and Christianity, 20: 250-259. 
Smith, T. W. (1992): Hostility and health: current status of a psychosomatic hypothesis. Health Psychology, 11: 139-150.

Speiers, A. (2004): Forgiveness as a secondary prevention strategy for victims of interpersonal crime. Australian Psychiatry, 12: 261-263.

Subkoviak, M. J., Enright, R. D., Wu, C., Gassin, E. A., Freedman, S., Olson, L. M., Sarinopoulos, I. (1995): Measuring interpersonal forgiveness in late adolescence and middle adulthood. Journal of Adolescence, 18: 641-655.

Tangney, J. P., Fee, R., Reinsmith, C., Boone, A. L., Lee, N. (1999): Assessing individual differences in the propensity to forgive. Elöadás az American Psychological Association éves kongresszusán, Bostonban.

Taylor, S. E., Klein, L. C., Lewis, B. P., Gruenewald, T., L., Gurung, R. A., Updegraff, J. A. (2000): Biobehavioral responses to stress in females: Tend-and-befriend, not fight-orflight. Psychological Review, 107: 411-429.

Thoresen, C. E., Harris, A. H. S., Luskin, F. (2000): Forgiveness and health: an unanswered question. In McCullough, M. E., Pargament, K. I., Thorsen, C. E. (eds): Forgiveness: Theory, Research and Practice. Guilford, New York, 163-192.

Toussaint, L. L., Webb, J. R. (2005): Theoretical and empirical connections between forgiveness, mental health, and well-being. In Worthington, E. L. (ed.): Handbook of Forgiveness. Brunner-Routledge, New York, 349-362.

Wade, N. G. (1989): The Development of a Scale to Measure Forgiveness. Publikálatlan doktori disszertáció. Fuller Graduate School of Psychology, Pasadena, CA.

Wade, N. G., Worthington, E. L. (2005): In search of a common core: a content analysis of interventions to promote forgiveness. Psychotherapy: Theory, Practice, Training, 42: 160-177.

Wade, N. G., Worthington, E. L, Meyer, J. E. (2005): But do they work? A meta-analysis of group interventions to promote forgiveness. In Worthington, E. L. (ed.): Handbook of Forgiveness. Brunner-Routledge, New York, 423-439.

Williams, R., Williams, V. (1993): Anger Kills: Seventeen Strategies for Controlling the Hostility that can Harm Your Health. Harper Perennial, New York.

Witvliet, C. V. O., Ludwig, T. E., Bauer, D. (2002): Please forgive me: transgressors' emotions and physiology during imagery of seeking forgiveness and victim responses. Journal of Psychology and Christianity, 21: 219-233.

Witvliet, C. V. O., Ludwig, T. E., Vander Laan, K. (2001): Granting forgiveness or harboring grudges: implications for emotion, physiology, and health. Psychological Science, 12: 117-123.

Worthington, E. L., Sandage, S. J., Berry, J. W. (2000): Group interventions to promote forgiveness: what researchers and clinicans ougth to know. In McCullough, M. E., Pargament, K. I., Thorsen, C. E. (eds): Forgiveness: Theory, Research and Practice. Guilford. New York, 228-253.

Worthington, E. L., Scherer, M. (2004): Forgiveness is an emotion - focused coping strategy that can reduce health risks and promote health resilience: theory, review and hypotheses. Psychology and Health, 19: 385-405.

Worthington, E. L., Witvliet, C. V. O., Lerner, A. J., Scherer, M. (2005): Forgiveness in health research and medical practice. Explore, 1: 169-176. 


\section{SZONDY, MÁTÉ \\ THE PSYCHOLOGY OF FORGIVENESS: ITS ORIGIN, ITS EFFECTS AND ITS PROMOTING}

Forgiveness is one of the possible responses after an interpersonal transgression. It means a prosocial change in the victim's cognitions, emotions and behavior. The positive effects of forgiveness on the mental and physical health status are well known. Its high level goes with low level of anxiety and depression and it can reduce the stress response of the body (cortisol and cardiovascular reactivity). Based on its effects we can define forgiveness as an emotion-focused coping strategy that can reduce the stress of an offence. In the last years a lot of intervention techniques were developed which goal is to support and to promote forgiveness. These methods effectively promote the willingness to forgive.

Keywords: forgiveness, effects of forgiveness, interventions to promote forgiveness 